\title{
IMPACT OF FINANCIAL RISK ON THE OPERATION OF START-UPS
}

\author{
Ryszard Pukala ${ }^{1}$ \\ ${ }^{1}$ Bronislaw Markiewicz State Higher School of Technology and Economics in Jaroslaw (Poland) \\ e-mail: ryszard.pukala@interia.pl
}

Received: 01 October 2020; Accepted: 14 October 2020; Published: 01 January 2021

\begin{abstract}
The aim of this study is to analyse the impact of financial risk on the operation of innovative, high-risk enterprises start-ups. Through advanced technologies and focusing on individual needs of recipients, such enterprises certainly fit the concept of the fourth industrial revolution. As part of their operational process start-ups are exposed to a broad spectrum of risks, among which the financial risks are particularly disruptive. With a clear objective of identifying financial risks that have the greatest impact on the operation of such enterprises, the study applied a questionnaire that used CAWI and CAPI methods and covered 202 start-ups active in Poland. The results of the questionnaire were subject to a statistical analysis to determine financial risks that influence the activity of start-ups to the greatest extent. The most important risks include the loss of financial liquidity and the lack of funds for continuing the development of an enterprise or a product. Therefore, we should assume that the innovative activity conducted by start-ups not only represents a method of gaining competitive advantage, but it is very often essential for the purpose of surviving on the market. Therefore, identifying operational risks and acting to limit their negative impact form an important aspect of the operation of start-ups.
\end{abstract}

Keywords: start-up, innovative enterprise, corporate finance, risk, risk management

JEL classification: D24, D81, D90.

\section{Citation:}

Pukala, R. 2021. Impact of financial risk on the operation of start-ups. Access to science, business, innovation in digital economy, ACCESS Press, 2(1): 40-49. https://doi.org/10.46656/access.2021.2.1(4)

\section{INTRODUCTION}

The neoclassical economic model explains the way business entities behave based on several fundamental assumptions as to their features and manner of operation. According to these assumptions, the entities (Solek, 2010):

- are rational,

- act based on full and perfect information and have unlimited means for the processing thereof,

- aim at maximising expected utility (as regards consumers) or maximising profits (as regards companies),

- act in a narrowly understood own interest i.e., without taking account of the utility of other entities,

- have coherent preferences, also in terms of time, consistent with the model of exponentially discounted utility,

- make decisions following the Bayesian rules of inference, 
- treat their income and resources interchangeably i.e., as not classified as to their source or target.

Modern enterprises operating in a turbulent market environment, under conditions imposed by the fourth industrial revolution, dynamic development of financial markets as well as increased risk and uncertainty, should consider changes taking place in an approach to financial management (Knight, 1921). This applies not only to a possibility of selecting sources, forms and instruments of capital acquisition and allocation, but also to changes in the concept of operation as part of executed financial strategies aimed at increasing the value of an enterprise and achieving market success. A lot of businesses are looking for innovative ways to improve efficiency and maintain competitive advantage in order to survive (Bacho et al, 2019; Kurmanov et al, 2018; Pukala et al, 2019). Three main areas can be distinguished in the decision-making process applied by contemporary enterprises. They relate to (Lukasik, 2007):

- acquisition of capital and shaping its structure,

- allocation and efficient use of capital, which has impact on, among others, the scope and manner of connecting with other market players and the structure of assets,

- risk management, i.e., the scope of risk, assessment of its undesirable consequences as well as possibility and degree of protection against the volatile nature of basic market parameters, taking account of consequences of broader exposure of an enterprise to risk.

The first theoretical and empirical studies of benefits an enterprise obtains from risk management were based on considering the consequences of using insurance, and later also derivatives, as risk management tools (Willet, 1901). In this perspective, protection against the impact of risk was explained through the risk aversion phenomenon, which stems from the expected utility hypothesis (Lukasik, 2007). It is worth mentioning that the expected utility hypothesis was originated by $\mathrm{N}$. Bernoulli already in the $18^{\text {th }}$ century and was later developed by J. von Neuman and O. Morgenstern in the mid- $20^{\text {th }}$ century. The latter scientists assumed that a rational market participant should always make (and thus, it makes) decisions that maximise its utility. Therefore, it is a normative theory of selection, the essence of which lies not in describing an actual behaviour of entities when faced with a choice, but in indicating actions aimed at maximising utility functions. On the grounds of the expected utility hypothesis, a criterion of classifying decision-making alternatives is a certainty equivalent - corresponding to a sum of cash a decision-making entity is ready to accept with zero risk in return for a benefit burdened with risk. Therefore, it constitutes a normative model of making decisions under conditions of risk (Pukala, 2016).

Differences in the level of expected utility are related to the matter of risk aversion. The basic measure of risk aversion is a certainty equivalent. It is expressed as a certain (guaranteed) amount that safeguards the same level of utility as an uncertain (risky) bet. Thus, this is the price a person who exhibits risk aversion is willing to pay for eliminating the risk (Wieczorek-Kosmala, 2017). The risk is also perceived as the maximum loss for a certain period of time, with a certain confidence interval (Radukanov, 2017). 
We need to stress that risk aversion is inherently related to the concept of expected risk premium. As indicated by A. Damodaran, the premium (RP) represents a difference between the possible, uncertain result (V) and the equivalent of certainty (V') (Damodaran, 2009):

$$
R P=V-V^{\prime}
$$

Based on this assumption, we need to declare that with an increase in the risk aversion level, the risk premium increases as well. It shapes the economic balance of an enterprise, in particular the capital balance. Therefore, a price offer of a producer (start-up) should guarantee the coverage of costs of manufacturing and acquiring additional revenues that allow further development.

In their developmental cycle, start-ups go through stages that are burdened with remarkably high risk, which limits or even prevents the acquisition of outside capital. In such case, hybrid financing instruments become an alternative source of capital acquisition, as an enterprise cannot demonstrate creditworthiness or issuance capacity due to the amount of surplus cash generated from business operations or the innovation level of an undertaking (Lukasik, 2011). In this context we need to examine the question of return on capital, expressed as a level of expectations as regards maximising benefits from investment and based on a correlation:

$$
R=\frac{P}{I}
$$

where:

$R$ - return on invested capital,

$P$ - expected results,

I - invested amount.

When assessing the expected benefits, consisting of a difference between the present value and the future value of invested capital, one needs to consider the investment risk as well. In such case, the amount of expected return on capital consists of a risk-free rate and a risk premium:

$$
E(R)=R_{R F}+R P
$$

where:

$E(R)$ - expected return on capital,

$R_{R F}$ - risk-free rate,

$R P$ - risk premium.

The risk-free rate $\left(\mathrm{R}_{\mathrm{rf}}\right)$ is equal to a rate of income of an investor that is achievable when investing capital in the project without any risk (Duliniec, 1998). In a model perspective, the dependence of the rate of return on capital on the risk is presented in Chart 1. 
Chart 1. Rate of return on capital versus risk (a model presentation)

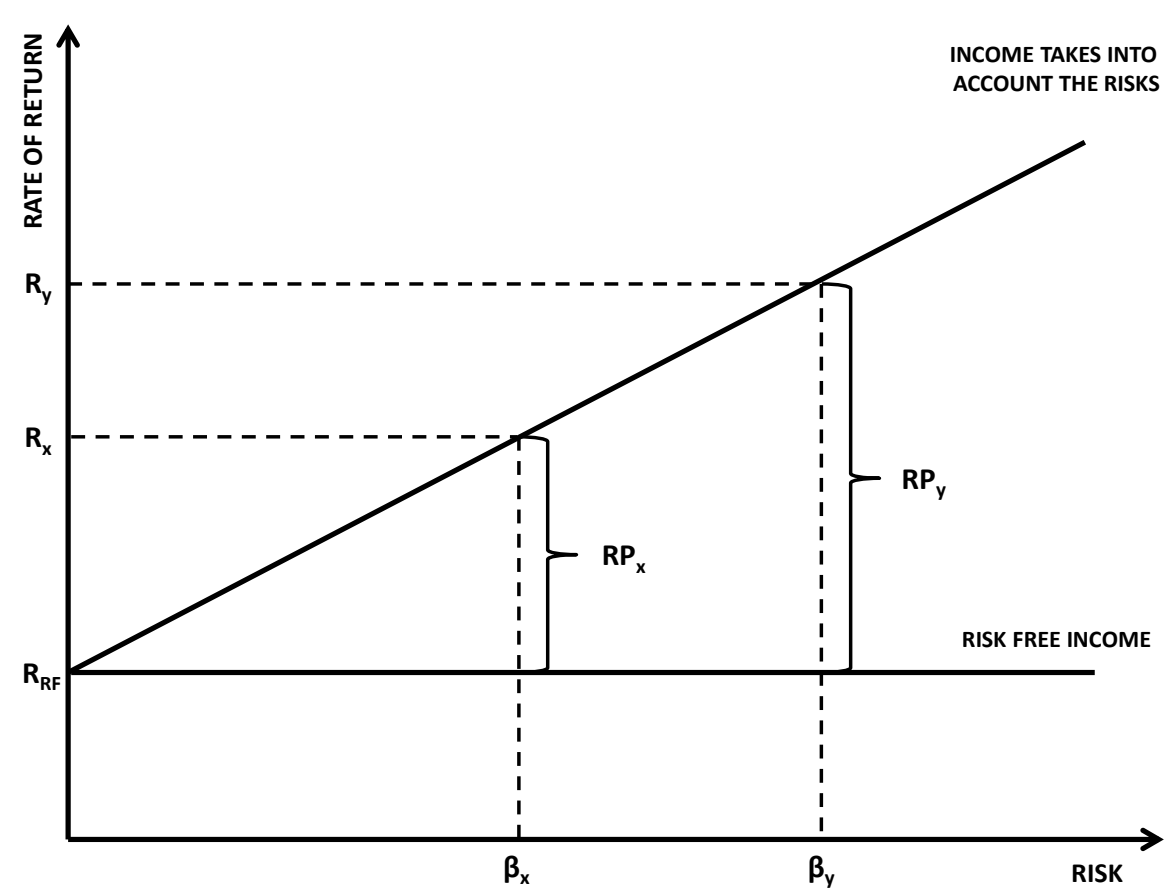

Source: M. Wieczorek-Kosmala, Kapitat ryzyka w przedsiębiorstwie z perspektywy zintegrowanego zarządzania ryzykiem, CeDeWu, Warszawa 2017, p.29 (in Polish).

where:

$\mathrm{R}_{\mathrm{RF}}$ - risk-free rate,

$\beta_{\mathrm{x}}, \beta_{\mathrm{y}}-$ risk of investor in project $\mathrm{X}$ and $\mathrm{Y}$ respectively,

$R_{x}, R_{y}$ - expected rate of return on investment in project $X$ and $Y$ respectively,

$\mathrm{RP}_{\mathrm{x}}, \mathrm{RP}_{\mathrm{y}}$ - risk premium for project $\mathrm{X}$ and $\mathrm{Y}$ respectively.

Through introducing innovative solutions that bring about new products or services to the market, start-ups conduct their business activity under conditions that are difficult to predict and define precisely. Therefore, the enterprise's demand on capital also depends on its exposure to risk, which results from the conducted activity. The capital invested in the enterprise, both own and external, aims at financing net operating assets (Duliniec, 2018). Apart from the operating capital, start-ups should accumulate an additional capital that makes it possible to cover the effects of different types of risks (Pukala, 2019).

Decisions concerning the amount and nature of capital intended for risk coverage result from a risk management method adopted by a given enterprise. In this area two basic methods exist as regards securing an enterprise against the effects of risks that can have an adverse impact on the results of operation and cause the emergence of financial problems (Pukala \& Petrova, 2019). The first one is risk retention, at the same time providing sources of financing that are necessary to cover potential losses arising from adverse occurrences. 
The other is transferring risk onto other entities, among others, insurers, issuers of derivatives or capital market investors. Both methods require identification of sources and areas exposed to risk.

Taking actions in the field of risk management is an important method of limiting the effects of risk. According to D. Mayers and C.W. Smith, benefits from risk management can be analysed in three main areas (Mayers \& Smith, 1982):

- reducing costs of bankruptcy,

- reducing tax burdens,

- positive impact on investments of an enterprise through eliminating the problem of underinvestment.

Financial risk, posing a serious threat to the operation of start-ups, is the one that directly influences financial results of an enterprise. It can be manifested in a situation where a loss of money or valuable assets occurs. In other words, each financial service or transaction is related to an inherent risk of loss (Shafer, 1996). It is also related to changes in the structure of sources of financing the activity of an enterprise, i.e., to changes in a relationship between own capitals and outside capitals that have impact on the financial result of an enterprise; an assessment of such risk can be performed by means of financial leverage (Nowak, 2010). In the case of start-ups, we can apply a definition of financial risk proposed by the Bank for International Settlements, according to which it is related to making financial decisions concerning methods of financing a business activity of an entity.

By making financial decisions, an enterprise also takes risk related to its operation, especially when it concerns investments in its own development. Financial risk management is an important aspect, as it is a set of rules that enable an enterprise to optimise a method of absorbing financial risk. This set of rules should also contain a method of monitoring actions that are burdened with risk as well as implementing and monitoring the risk management process itself.

\section{Methodology and results}

The study has covered a group of 202 start-ups conducting business activity in the entire territory of Poland and applied questionnaires as well as CAWI (Computer Assisted Web Interview) and CAPI (Computer Assisted Telephone Interview) methods. Apart from the information about a start-up, all remaining questions were formulated by use of a 5 -grade scale, where 1 means the lowest impact/materiality and 5 - the highest impact/materiality. The data obtained through questionnaires have been subject to a statistical analysis, including a multiple regression analysis.

The analysis has used descriptive statistical methods (Dobosz, 2001; Mynarski, 2003), consisting in determining basic statistical measures that allow describing the distribution of results of respondents' answers to subsequent questions in a questionnaire. The measures were as follows:

- location (point of concentration): arithmetic mean $(\bar{x})$,

- dispersion: standard deviation $\left(\mathrm{S}_{\mathrm{d}}\right)$, 
- distribution shape: skewness.

Verification of zero hypotheses has also been performed. In each applied method of verification of hypotheses, a materiality level $\alpha=0.05$ has been adopted. A decision to reject (or determining the lack of grounds for rejection of) the zero hypothesis was made based on the test probability (p). The zero hypothesis was rejected when the test probability was lower or equal to 0.05 .

Based on the conducted analysis, the risks that are closely related to a start-up's financial standing have been classified to a group of financial risks. 10 most important risks that in the view of start-ups can have the greatest impact on the operation of such enterprises have been selected. A list of financial risks adopted for analysis as well as basic statistical measures and results of the analysis of normality of distribution are presented in Table 1.

Table 1. Assessment of exposure to financial risk - basic statistical measures and results of the normality of distribution analysis

\begin{tabular}{|l|c|c|c|c|}
\hline \multirow{2}{*}{ Category } & \multicolumn{2}{c|}{ Statistical measures } & $\begin{array}{c}\text { Normality } \\
\text { analysis }\end{array}$ \\
\cline { 2 - 5 } & $\bar{x}$ & \multicolumn{1}{|c|}{$\mathbf{s}_{\mathbf{d}}$} & Skewness & $\mathbf{p}$ \\
\hline Loss of financial liquidity & 4,03 & 1,00 & $-0,81$ & 0,003 \\
\hline Availability of own capital & 3,70 & 0,90 & $-0,38$ & 0,640 \\
\hline Availability of bank credits & 3,43 & 1,00 & $-0,35$ & 0,248 \\
\hline Availability of other external sources of financing & 3,50 & 1,00 & $-0,36$ & 0,061 \\
\hline Operating costs higher than planned & 3,85 & 0,96 & $-0,51$ & 0,063 \\
\hline Enterprise profitability too low & 3,65 & 0,98 & $-0,34$ & 0,731 \\
\hline Lack of funds for further development of an enterprise & 3,95 & 0,92 & $-0,41$ & 0,064 \\
\hline $\begin{array}{l}\text { Lack of funds for further development of } \\
\text { product/service }\end{array}$ & 3,87 & 0,95 & $-0,40$ & 0,178 \\
\hline Lack of funds for development of a sales network & 3,85 & 0,99 & $-0,66$ & 0,079 \\
\hline Lack of funds for advertising & 3,63 & 0,96 & $-0,38$ & 0,565 \\
\hline
\end{tabular}

Source: author's own calculations.

Dynamic changeability of the environment and its unstable conditions should be received by start-ups as a signal of concern as to development directions and sales results, therefore such enterprises should focus on minimising the financial risk in order to eliminate problems with the repayment of liabilities, regardless of what the risks entail.

Calculations performed as part of the study indicate the following:

- arithmetic mean values - between 3.63 and 4.03 - attest to the fact that the respondents perceive the level (impact) of exposure to risk as average or high, 
- standard deviation values range between 0.90 and 1.00 (coefficient of variation ranging between 24 and $43 \%$ ), therefore the diversity of ratings within particular categories is typical for this type of studies,

- skewness modules - between 0.34 and 0.81 - indicate slight asymmetry in the distribution of results of assessment within particular categories; nearly all values indicate left-side asymmetry (negative coefficient values),

- chi-square compliance test allows us to assume that normal distributions ( $p>0.05)$ represent the majority of empirical distributions; distribution of results in category $1(\mathrm{p}<0.05)$ is the sole exception.

The financial risk is an incredibly important element of start-ups' operation, as such enterprises most often have limited opportunities to acquire capital for further development. Therefore, they often face underinvestment, which takes place in a situation where the use of external financing is inefficient due to too high a marginal cost of acquiring additional capital. The reason for increased costs of financing can include, among others, the level of start-up debt, ensuing a higher risk premium and additional transaction costs.

In the case of cash funds deficit, an enterprise misses a chance to engage in investment projects that (assuming the financing through own funds) have a positive present value and could potentially increase the value of an enterprise. An alternative could be the acquisition of external financing or issuance of additional shares; however, the high cost of capital can reduce profitability of a project, leading to lost opportunities as regards external financing or even to the rejection of the project (due to negative NPV). Another aspect that has an adverse impact on the cost of external capital is the fact that most frequently the creditors negatively assess the standing of a start-up because of high susceptibility of its results to external and internal factors related to achieving product scalability.

Innovative activity conducted by start-ups is not only a method of gaining competitive advantage and achieving the leading position, but also, very often, it is a precondition for survival on the market. In this regard, taking actions that limit or eliminate particular risk categories is of remarkable importance. The ranking of risks, according to respondents' indications, is presented in Chart 2.

As indicated by the results of conducted analyses, the following have the greatest impact on the operation of start-ups (arithmetic mean values between 3.85 and 4.03): loss of financial liquidity, lack of funds for further development of an enterprise, lack of funds for further development of a product, costs of activity higher than planned and the lack of funds for the development of sales. Therefore, these risks are of key significance for start-ups, as their emergence may lead to insolvency. 
Chart 2. Ranking of financial risks that have impact on the operation of start-ups

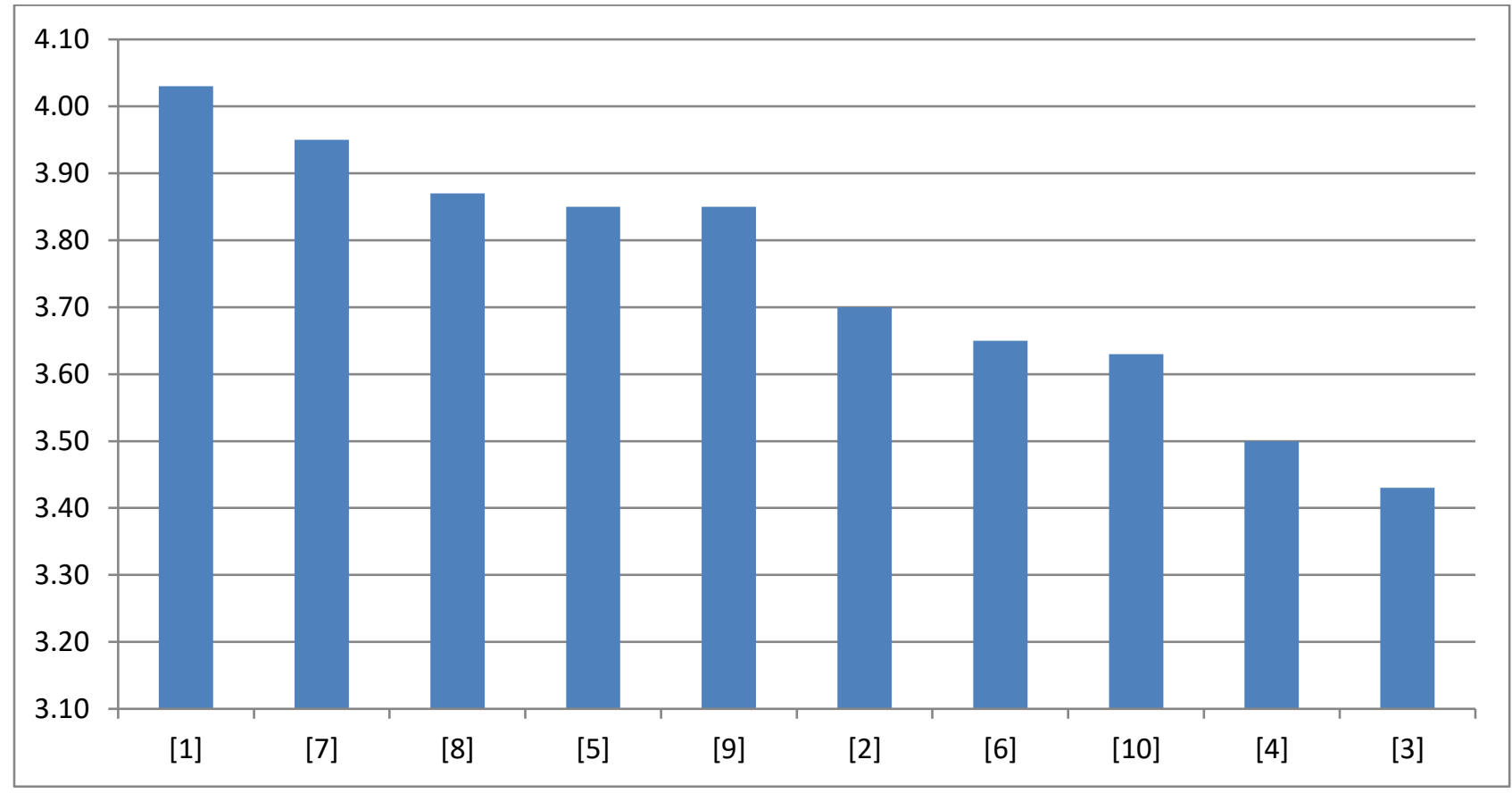

Source: author's own calculations. Description of categories as in Table 1.

\section{CONCLUSION}

Conducting business activity by start-ups for the purpose of own development and further operation requires the acquisition of sources of financing that correspond to operational and investment needs. To safeguard financial liquidity and continuity of operation, the acquisition of the abovementioned sources is of key importance, both in terms of value and time. All planned outlays should be reflected in the planned proceeds of cash. Each source of financing entails slightly different conditions of acquiring funds and financing costs; consequences of using certain sources can also vary (insolvency risk level, relationships with investors, impact on enterprise value shaping, etc.). Apart from acquiring developmental capital, start-ups should also undertake actions aimed at limiting the effects of various risks, especially the financial risks, through implementing risk management procedures and applying risk financing methods, such as insurance. Such measures will certainly have a positive impact on the development of such enterprises and will help them gain a competitive advantage in a turbulent market environment.

\section{Conflict of interests}

The authors declare no conflict of interest. 


\section{References}

Bacho, R., Pukala, R., Hlibko, S., Vnukova, N., Pola, P. (2019). Information Management: The Key Driver of the Economic System's Development. Marketing and Management of Innovations, 2019, 3. P. 297-307. URL: http://doi.org/10.21272/mmi.2019.3-23.

Borch K. (1967). The Theory of Risk, Journal of the Royal Statistical Society, Series B 29, no. 3.

Damodaran A. (2009). Ryzyko strategiczne. Podstawy teorii i praktyki. Wydawnictwa Akademickie i Profesjonalne, Warszawa (in Polish).

Dobosz M. (2001). Wspomagana komputerowo statystyczna analiza wyników badań. Akademicka Oficyna Wydawnicza EXIT, Warszawa (in Polish).

Duliniec A. (1998). Struktura i koszt kapitału w przedsiębiorstwie, PWN, Warszawa (in Polish).

Duliniec A. (2018), Determinanty polityki finansowej przedsiębiorstwa, „Finansowy Kwartalnik Internetowy eFinanse", http://e-finanse.com/artykuly/3.pdf (in Polish).

Knight F.H. (1921). Risk, Uncertainty and Profit, University of Illinois at Urbana-Champaign's Academy for Entrepreneurial Leadership Historical Research Reference in Entrepreneurship.

Kurmanov N.A., Toksanova A.N. Mukhamedzhanov A.A., Syrlybayeva N.Sh.; M.M., Petrova. (2018). Analysis of efficiency of innovation activities in the countries of the Eurasian Economic Union. The Journal of Economic Research \& Business Administration, [S.1.], v. 126, n. 4, p. 35-51. eISSN 2617-7161. pISSN: 1563-0358. AL-FARABI Kazakh National University, Available at: https://be.kaznu.kz/index.php/math/article/view/2026

Łukasik G. (2007). Przedsiębiorstwo na rynku kapitałowym (red.), Prace Naukowe Akademia Ekonomiczna w Katowicach, Katowice (in Polish).

Łukasik G., (2011). Rola hybrydowych instrumentów finansowych w strategii finansowania rozwoju przedsiębiorstwa, Problemy Zarządzania, vol 9, nr 34, t. 2 (in Polish).

Mayers D., Smith C.W. (1982). On the Corporate Demand for Insurance, Journal of Business, 55 (2).

Mynarski S. (2003). Analiza danych rynkowych i marketingowych z wykorzystaniem programu Statistica. Wyd. AE, Kraków (in Polish).

Nowak E. (2010). Rachunkowość w zarządzaniu ryzykiem w przedsiębiorstwie, [w:] Nowak E. (red.), Zarządzanie ryzykiem działalności przedsiębiorstwa, PWE, Warszawa 2010 (in Polish).

Pukala R. (2016). Use of neural networks in risk assessment and optimization of insurance cover in innovative enterprises, Economics and Management, Volume 8, Issue 3.

Pukala, R. (2019). Start-ups as an Element Supporting the Development of the Mining and Energy Sector, IVth International Innovative Mining Symposium, E3S Web of Conferences 105, 04015, https://doi.org/10.1051/e3sconf/201910504015.

Pukala, R., Petrova, M. (2019). Application of the AHP Method to Select an Optimal Source of Financing Innovation in the Mining Sector, IVth International Innovative Mining Symposium, E3S Web of Conferences 105, 04034, https://doi.org/10.1051/e3sconf/201910504034.

Pukala, R., Hlibko, S., Vnukova, N., Davidenko, D. (2019). Usage of E-Technologies to Enhance Infocommunication in Financing Innovation. IEEE International Scientific-Practical Conference "Problems of Infocommunications Science and Technology". PIS S\&T 2019. October 8-11, 2019. Kyiv, Ukraine. P. 157-160.

Radukanov S. (2017). Market risk assessment under risk methodology (VaR)-specifications and application, SocioEconomic Analysis, Vol. 9, issue 2, Veliko Tarnovo, 2017 p. 182 - 194

Shafer G. (1996). The Significance of Jacob Bernoulli’s Ars Conjectandi for the Philosophy of Probability Today, Journal of Econometrics, 75 (1), 1996.

Sołek, A. (2010). Ekonomia behawioralna a ekonomia neoklasyczna, Zeszyty Naukowe nr 8, PTE, Kraków (in Polish).

Wieczorek-Kosmala M. (2017). Kapitał ryzyka w przedsiębiorstwie z perspektywy zintegrowanego zarządzania ryzykiem, Wydawnictwo CeDeWu, Warszawa (in Polish).

Willet A.H. (1901). The Economic Theory of Risk and Insurance, Philadelphia. 
About the author:

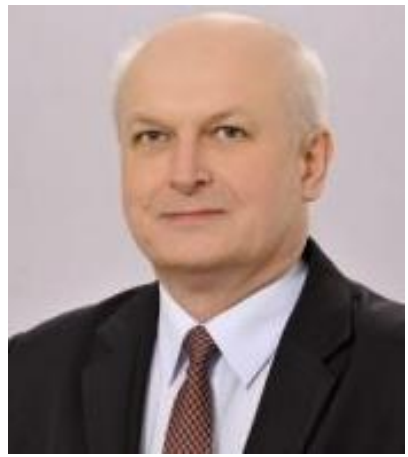

\section{Ryszard PUKALA,}

Ph.D. (Economics), the main issues he deals with as part of the conducted research work focus on systemic risk, financial markets, identifying and managing business activity risks, using instruments aimed at financing the effects of risk materialization, with particular attention paid to insurance and the issues of innovation in the economy and enterprises. An author of many scientific publications and conference materials issued in prominent magazines as well as domestic and foreign publishing houses as well as a head of national and international research projects. Member of the Polish Economic Society.

ORCID ID: https://orcid.org/0000-0002-2943-8482

Copyright (C) 2020 by author(s) and ACCESS Publishing Press This work is licensed under the Creative Commons Attribution International License (CC BY) 